\title{
TELAAH SOCIOLEGAL TERHADAP TERWUJUDNYA KEDAULATAN HAK ATAS SUMBER DAYA AIR
}

(Sociolegal Study on Actualizing the Sovereign Rights on Water Resources)

\author{
Ria Casmi Arrsa \\ Peneliti PPOTODA Universitas Brawijaya \\ JI. MT. Haryono No.169 Malang, Jawa Timur \\ Email:ppotoda@gmail.com,website:http://www.ppotoda.org
}

Naskah diterima: 16 Juni 2015; revisi: 10 Agustus 2015; disetujui: 19 Agustus 2015

\begin{abstract}
Abstrak
Amanat Pasal 33 ayat (3) Undang-Undang Dasar Negara Republik Indonesia Tahun 1945 menyebutkan bahwa, "Bumi dan air dan kekayaan alam yang terkandung di dalamnya dikuasai oleh negara dan dipergunakan untuk sebesarbesar kemakmuran rakyat". Namun demikian dalam ranah praktek penyelenggaraan negara maka pengelolaan Sumber Daya Air di Indonesia mengalami pergeseran paradigma pasca ditetapkannya Undang-Undang Nomor 7 Tahun 2004 tentang Sumber Daya Air yang cenderung mengarah pada praktek privatisasi sehingga sering memicu terjadinya konflik sosial. Untuk mengkaji permasalahan yang ada, maka dalam penulisan karya ilmiah ini menggunakan metode Socio Legal. Dapat disimpulkan bahwa pergeseran paradigma penguasaan sumber daya air oleh swasta dan/atau pihak asing yang bersifat monopoli dan eksploitatif memiliki potensi untuk menimbulkan konflik sosial. Untuk itu diperlukan revisi terhadap ketentuan UndangUndang Nomor 7 Tahun 2004 tentang Sumber Daya Air guna mewujudkan kedaulatan atas Sumber Daya Air dan melakukan harmonisasi dan sinkronisasi hukum terhadap aturan pelaksanaan dari Undang-Undang tersebut. Pemerintah juga perlu melakukan identifikasi guna mengeluarkan kebijakan agar sumber daya air dimasukkan dalam kategori bidang usaha yang tertutup dari penanaman modal.
\end{abstract}

Kata Kunci: rekonstruksi, hukum, sumber daya air

\section{Abstract}

Mandate of Article 33 paragraph (3) of the Constitution of the Republic of Indonesia Year 1945 states that, "The earth and water and natural resources contained therein shall be controlled by the state and used for maximizing peopleprosperity". Constitutional design is essentially gave birth to the idea of Neo-Socialism of Indonesia nations toward the management of water resources oriented to the overall prosperity of the people. However, in the realm of the state governing, practice management of water resources in Indonesia experienced a paradigm shift after the enactment of Law Number 7 year 2004 regarding Water Resources which intended to lead of privatization practices that potentially lead to social conflict. The constitutional court through the Constitutional Court Decision No. 85/ PUU-XII/2013 opened a new chapter in the management of Water Resources Indonesia directed at political reconstruction prismatic design rights law Mastering State Upper Water Resources based on the values of social justice and popular participation in order to ensure the realization of the people's sovereignty on Water Resources. The final goal of this study was expected tobridge formation of paradigmatic legal framework for the management of water resources in order to reach future welfare.

Keywords: reconstruction, law, water resources 


\section{A. Pendahuluan}

Perkembangan hukum dalam sektor sumber daya alam berjalan sangat pesat ditengah laju investasi yang menghendaki adanya jaminan kepastian hukum bagi dunia usaha untuk menjalankan aktifitas perekonomian di bidang ekplorasi terhadap sumber daya alam Indonesia. Salah satu aspek sumber daya alam yang memiliki keterkaitan dengan hajat hidup orang banyak adalah keberadaan sumber daya air yang berperan sebagai sumber kehidupan dan penghidupan bagi manusia. Sehubungan dengan hal itu maka arah politik hukum terhadap pemanfaatan dan/atau pendayagunaan sumber daya air di Indonesia wajib hukumnya untuk dikonstruksikan sebagai bagian dari tanggung jawab negara (state responsibility) untuk memenuhi hajat hidup warga negara Indonesia akan kebutuhan air dalam berbagai aktifitasnya. Oleh karenanya dalam konteks kenegaraan keberadaan air merupakan salah satu aspek yang menjadi penguasaan oleh negara sebagaimana amanat konstitusi.

Demikian halnya dalam perspektif sejarah perkembangan HAM, isu hak atas lingkungan yang sehat maupun sumber daya alam merupakan hak kolektif generasi ketiga. Dalam model demikian ini, isu lingkungan hidup dan pengelolaan SDA tidak lagi dipahami sebagai isu individual akan tetapi lebih dipahami sebagai isu kolektif. Dengan demikian, bagi negara, adanya hak asasi manusia atas lingkungan hidup dan pemanfaatan sumber daya alam yang baik, sehat dan berkelanjutan menjadi kewajiban negara menjamin terpenuhinya hak-hak tersebut. ${ }^{1}$
Bentuk pertanggung jawaban negara terhadap pemenuhan hak warga negara atas air dipandang penting mengingat bahwa di dalam ketentuan UUD Negara Republik Indonesia Pasal 33 Ayat (1) menyebutkan bahwa Perekonomian disusun sebagai usaha bersama berdasar atas asas kekeluargaan. Ketentuan Ayat (2) Cabangcabang produksi yang penting bagi negara dan yang menguasai hajat hidup orang banyak dikuasai oleh negara. Sedangkan Ayat (3) secara tegas menyebutkan, "Bumidan air dan kekayaan alam yang terkandung di dalamnya dikuasai oleh negara dan dipergunakan untuk sebesarbesar kemakmuran rakyat". Dalam konstruksi konstitusi selanjutnya sebagaimana termaktub di dalam Pasal 33 Ayat (4) Perekonomian nasional diselenggarakan berdasar atas demokrasi ekonomi dengan prinsip kebersamaan, efisiensi berkeadilan, berkelanjutan, berwawasan lingkungan, kemandirian, serta dengan menjaga keseimbangan kemajuan dan kesatuan ekonomi nasional.

Beranjak pada konstruksi konstitusi diatas maka dalam ranah kebijakan dan regulasi Pemerintah dan DPR pada awalnya menetapkan Undang-Undang Nomor 11 Tahun 1974 tentang Pengairan sebagaimana telah dicabut dan dinyatakan tidak berlaku pasca ditetapkannya Undang-Undang Nomor 7 Tahun 2004 tentang Sumber Daya Air (UU SDA). Namun demikian seiring dengan perkembangan waktu maka keberadaan air sudah mengalami pergeseran paradigma pengelolaan manakala air sudah tidak lagi dipandang sebagai barang bebas yang memiliki fungsi sosial akan tetapi telah menjadi

Bambang Sugiri, Pergeseran Kebijakan Hukum Pidana Tentang Pencemaran Lingkungan Hidup Dalam UndangUndang Nomor 32 Tahun 2009 Tentang Perlindungan Dan Pengelolaan Lingkungan Hidup, (Malang: Disertasi PDIH FH UB, 2012) hlm. 2. 
komoditas ekonomi yang cenderung mengarah pada privatisasi dan eksploitasi. ${ }^{2}$

Praktek privatisasi dan/atau eksploitasi sebagaimana dimaksud berkembang meluas karena adanya kebutuhan masyarakat terhadap air yang semakin meningkat sehingga mendorong lebih menguatnya nilai ekonomi air dibanding nilai dan fungsi sosialnya. Kondisi tersebut berpotensi menimbulkan konflik kepentingan antar sektor, antar wilayah dan berbagai pihak yang terkait dengan sumber daya air. Di sisi lain, pengelolaan sumber daya air yang lebih bersandar pada nilai ekonomi akan cenderung lebih memihak kepada pemilik modal serta dapat mengabaikan fungsi sosial sumber daya air. Untuk memahami perkembangan politik legislasi dibidang sumber daya air berikut penulis ilustrasikan melalui skema sebagai berikut:

\section{Skema 1}

Perkembangan Politik Legislasi di Bidang Sumber Daya Air

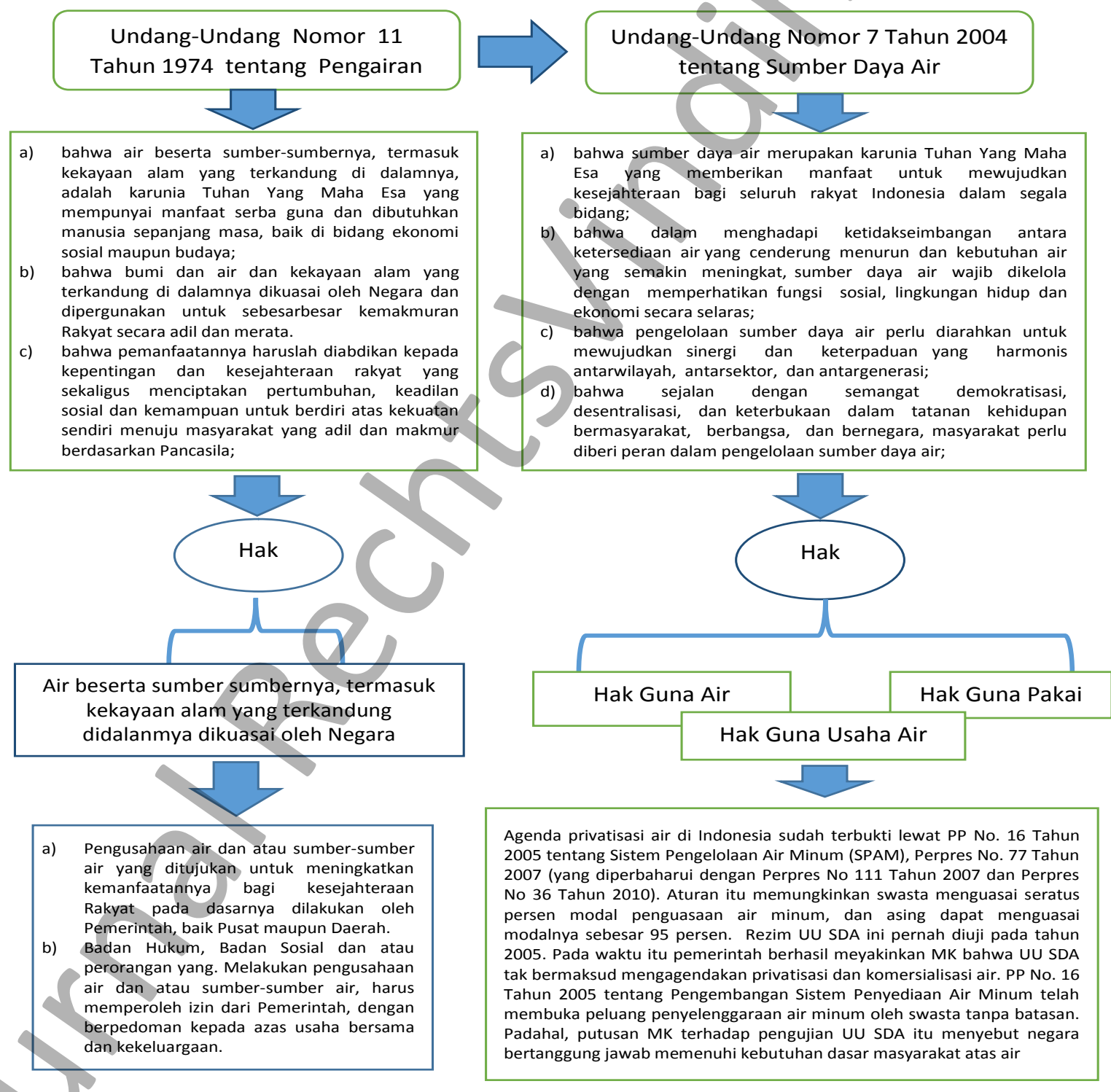

2 Endaryanta, Edwin, Politik Air di Indonesia: Penjarahan si Gedhang oleh Korporasi Aqua Danone, (Yogyakarta: Laboratorium Ilmu Pemerintahan, FISIPOL UGM, 2007) hlm. 14. 
Berdasarkan skema diatas maka ketersediaan dan pemenuhan air bagi warga negara merupakan bagian dari rezim hak konstitusional warga negara (Constitutional Rights) sebagaimana termaktub di dalam konstitusi. Air yang memiliki rumus $\mathrm{H}_{2} \mathrm{O}$ merupakan esensi kehidupan. Pada hakikatnya, air termasuk zat yang tidak dapat digantikan. Vitalitas air bagi kehidupan manusia sama seperti halnya oksigen $\left(\mathrm{O}_{2}\right)$. Dapat dikatakan tanpa air bukan hanya manusia tetapi semua mahluk hidup dimuka bumi ini tidak dapat bertahan hidup. Oleh karena itu hak untuk air (right to water) merupakan hak yang mendasar bagi kehidupan manusia. Berbagai kovenan di Perserikatan Bangsa-Bangsa (PBB) menyebutkan bahwa bukan hanya air itu sendiri yang merupakan hak, tetapi akses terhadap air bersih juga menjadi Hak Asasi Manusia (HAM). ${ }^{3}$

Namun demikan fakta menunjukkan bahwa pemenuhan hak atasair (the right to water) untuk sebagian penduduk dunia, termasuk Indonesia belum tercapai. Dari fakta itu mendorong upaya pemenuhan hak atas air dimasukkan sebagai salah satu tujuan pembangunan millenium atau disebut Millenium Development Goals (MDGs) sebagai target ke 10 (Sepuluh). Target tersebut ditetapkan sebagai upaya mengurangi setengah dari jumlah penduduk dunia yang tidak mempunyai akses air bersih dan sanitasi pada tahun 2015. Pencapaian target tersebut penting karena World Health Organization (WHO) pada tahun 2003 melaporkan bahwa dari 6 Miliar penduduk dunia masih terdapat
1,1 miliar orang yang tidak mempunyai akses terhadap air bersih dan 63\%-nya berada di Asia 28\% di Afrika, 7\% di Amerika Latin dan Karibia, dan $2 \%$ berada di Eropa. ${ }^{4}$

Ditengah situasi dan kondisi globalisasi ekonomi yang berujung pada praktek-praktek privatisasi dan/atau komersialisasi terhadap Sumber Daya Air menyebabkan potensi air yang ada di Indonesia menghadapi ancaman. Disinyalir pula pertumbuhan industri air minum dalam kemasan (AMDK) yang mengalami peningkatan pesat. Menjamurnya bisnis air minum dalam kemasan (AMDK) berimplikasi pada semakin banyaknya daerah yang menjadi sasaran eksploitasi air.

Sejumlah konflik terhadap pemanfaatan sumber daya air terus terjadi seiring dengan laju investasi yang cenderung detruktif terhadap keberlanjutan lingkungan hidup. Tengoklah misalnya eksploitasi air yang dilakukan oleh sebuah perusahaan multinasional di Desa Curug Goong, Padarincang, Serang, Banten. Masyarakat resah karena khawatir perusahaan akan menguasai sumber mata air Cirahab. ${ }^{5}$ Demikian halnya yang terjadi atas konflik antara PT. The Rayja dan masyarakat bulukerto Kecamatan Bumi Aji atas pendirian kawasan hotel dan resort diatas sumber mata air gemulo. Konflik terjadi disebabkan kegelisahan akan krisis air, dan kelemahan pemerintah sebab melanggar perundang-undangan yang berlaku. Mengikuti ketentuan tentang bangunan di sekitar kawasan sumber air jarak minimal seharusnya $200 \mathrm{~m}$. Dalam perencanaan jarak hotel yaitu $150 \mathrm{~m}$, dimana berpotensi akan merusak sumber air. ${ }^{6}$

Suteki, Rekonstruksi Politik Hukum Hak Atas Air Pro-Rakyat, (Malang: Surya Pena Gemilang, 2010), hlm. 3.

Suteki, Ibid, hlm. 3.

Mahkamah Konstitusi, Akhir Kisah Privatisasi Air (UU SDA Bertentangan dengan Konstitusi), (Jakarta: Majalah Konstitusi, 2015), hlm. 3.

6 Dilansir dari hasil pemantauan dan advokasi Pusat Pengembangan Otonomi Daerah (PPOTODA) Fakultas Hukum Universitas Brawijaya terhadap masyarakat Bulukerto Kecamatan Bumiaji Kota Batu Tahun 2013- Sekarang. 
Tidak berhenti pada kasus sebagaimana dimaksudkan diatas praktek ekploitasi terhadap sumber daya air terus berjalan seiring dengan laju pembangunan. Diketemukan pula konflik yang terjadi berupa penolakan warga Kabupaten Rembang terhadap pembangunan pabrik semen oleh PT. Semen Indonesia karena lokasi pabrik dan lokasi ekspolitasi penambangannya di wilayah Cekungan Air Tanah (CAT) Watuputih. Kawasan tersebut merupakan kawasan yang memiliki fungsi penyimpan cadangan air. Hasil penelitian Air Bawah Tanah di Gunung Watuputih oleh Dinas Pertambangan Provinsi Jawa Tengah pada Maret 1998 menjelaskan bahwa Gunung Watuputih dan sekitarnya secara fisiografis tergolong dalam tipe bentang alam karst.

Terdapat fenomena alam unik dengan adanya goa-goa alam dan sungai bawah tanah. Hasil pendataan lapangan yang dilakukan oleh Semarang Caver Association (SCA) dan Jaringan Masyarakat Peduli Pegunungan Kendeng (JMPPK) Rembang, terdapat goa-goa yang tersebar di wilayah tersebut di antara goa tersebut merupakan goa yang memiliki sungai-sungai bawah tanah yang masih aktif. Izin usaha pertambangan yang dikeluarkan oleh pemerintah Kabupaten/Rembang merekomendasikan kepada PT. Semen Gresik (Persero) Tbk untuk melakukan penambangan di area yang masuk ke dalam kawasan CAT Watuputih seluas 131,55 hektare $(1.315 .500$ $\mathrm{m} 2)$.

Jikalau kawasan tersebut diatas ditambang maka akan terdapat risiko besar yaitu potensi hilangnya sumber air. Selain daripada itu dampak ekologis akibat hilangnya fungsi resapan air pada kawasan CAT Watuputih, akan mengancaman 607.198 jiwa di 14 kecamatan, Kabupaten Rembang yang selama ini menggantungkan pada wilayah tersebut. Selain itu dalam konteks bencana, hilangnya fungsi resapan menyebabkan hilangnya jeda waktu air tersimpan sehingga pada saat musim hujan, air yang seharusnya terserap ke dalam tanah akan berubah menjadi air permukaan/run off. Pada saat air melebihi debit puncak air hujan yang datang akan cepat hilang sebagai aliran air permukaan $\mathrm{Hal}$ ini dapat mengakibatkan banjir di wilayah-wilayah dataran yang berhubungan langsung dengan Daerah Aliran Sungai (DAS) yang bermuara pada CAT Watuputih.

Penulis memandang bahwa kawasan Cekungan Air Tanah (CAT) Watuputih sebagai bentangan kawasan karst sehingga dilarang adanya aktivitas pertambangan. Jika pembangunan pabrik tetap dilanjutkan, maka fungsi resapan air kawasan CAT Watuputih akan hilang dan mengancam lebih dari 607.198 jiwa di 4 kecamatan yang kebutuhan airnya dipasok dari kawasan ini. Dalam konteks industrialisasi yang sedang menyeruak di Indonesia maka penulis memandang bahwa praktek empiris pembangunan dan investasi yang cenderung tidak memperhatikan daya dukung dan daya tampung terhadap keberlanjutan lingkungan hidup maka akan semakin mempercepat bencana ekologis seperti yang sekarang tengah mengancam banyak wilayah yang ada di Indonesia

Berdasarkan pada situasi dan kondisi konflik atas Sumber Daya Air dan ketercerabutan regulasi atas Sumber Daya Air sebagaimana dipaparkan diatas maka arah politik legislasi terhadap UU SDA menuai berbagai perdebatan. Meskipun Mahkamah Konstitusi telah memberikan putusan terhadap UndangUndang a quo melalui Putusan Nomor 058059-060-063/PUU-II/2004 dan Nomor 008/ PUU-III/2005 dan menyatakan konstitusional 
bersyarat namun penjabaran terhadap Putusan Mahkamah Konstitusi tersebut tidaklah dijalankan sepenuhnya. Hal-ihwal ini tidak terlepas dari substansi Undang-Undang dimaksud yang memberi kelonggaran pada pemodal asing dalam melakukan pengelolaan terhadap sumber daya air.

Pada akhirnya Mahkamah Konstitusi (MK) memberikan penegasan melalui Putusan Nomor 85/PUU-XII/2013 yang mana di dalam amar Putusannya membatalkan keberlakuan secara keseluruhan Undang-Undang Nomor 7 Tahun 2004 tentang Sumber Daya Air karena tidak memenuhi enam prinsip dasar pembatasan pengelolaan sumber daya air. Dalam pertimbangannya, MK menyatakan bahwa sumber daya air sebagai bagian dari hak asasi, sumber daya yang terdapat pada air juga diperlukan manusia untuk memenuhi kebutuhan lainnya, seperti untuk pengairan pertanian, pembangkit tenaga listrik, dan untuk keperluan industri, yang mempunyai andil penting bagi kemajuan kehidupan manusia dan menjadi faktor penting pula bagi manusia untuk dapat hidup layak.

Persyaratan konstitusionalitas UU SDA tersebut adalah bahwa UU SDA dalam pelaksanaannya harus menjamin terwujudnya amanat konstitusi tentang hak penguasaan negara atas air. Hak penguasaan negara atas air itu dapat dikatakan ada bilamana negara, yang oleh UUD 1945 diberi mandat untuk membuat kebijakan (beleid), masih memegang kendali dalam melaksanakan tindakan pengurusan (bestuursdaad), tindakan pengaturan (regelendaad), tindakan pengelolaan (beheersdaad), dan tindakan pengawasan (toezichthoudensdaad).
Beranjak pada uraian diatas maka kedaulatan negara terhadap sumber daya air merupakan suatu keniscayaan dalam rangka memenuhi hakhak konstitusional warga negara (constitutional rights). Penguasaan negara atas sumber daya air merupakan bagian yang inheren terhadap keberlanjutan peran dan tanggung jawab negara yang secara mutlak harus dijalankan sehingga keberadaan sumber daya air tidak diserahkan pada mekanisme intervensi modal asing dan/ atau sistem pasar yang cenderung destruktif terhadap fungsi ekologis. Tujuan akhir dari penelitian ini diharapkan dapat menjembatani pembentukan kerangka hukum paradigmatik terhadap pengelolaan sumber daya air yang mensejahterakan rakyat di masa yang akan datang.

Berdasarkan uraian mengenai latar belakang diatas maka dalam penulisan karya ilmiah ini di rumuskan beberapa permasalahan antara lain:pertama, bagaimanakah optik sociolegal menelaah Putusan Mahkamah Konstitusi Nomor 85/PUU-XII/2013 terhadap uji materiil Undang-Undang Nomor 7 Tahun 2004 tentang Sumber Daya Air. Kedua, bagaimanakah arah politik hukum pengelolaan Sumber Daya Air pasca Putusan Mahkamah Konstitusi Nomor 85/ PUU-XII/2013 sebagai keniscayaan terwujudnya kedaulatan Sumber Daya Air di Indonesia.

\section{B. Metode Penelitian}

Dalam penulisan karya ilmiah ini penulis menelaah Putusan Mahkamah Konstitusi Nomor 85/PUU-XII/2013 terhadap uji materiil UndangUndang Nomor 7 Tahun 2004 tentang Sumber Daya Air dari perspektif Sociolegal. Sebagaimana diutarakan Soetandyo Wignyosoebroto ${ }^{7}$

Soetandyo Wignyosoebroto, Hukum Paradigma, Metode dan Masalah, (Jakarta: Elsam dan Huma, 2002) hlm. 78. 
Penelitian atau riset itu bermakna pencarian, yaitu pencarian jawab mengenai suatu masalah. Maka dengan demikian apa yang disebut metode penelitian itu pada asasnya akan merupakan metode (atau cara dan/atau prosedur) yang harus ditempuh agar orang bisa menemukan jawab yang boleh dipandang benar (dalam arti true, bukan atau tidak selalu dalam arti right atau just) guna menjawab masalah tertentu itu. Untuk mengkaji permasalahan yang ada, maka dalam penulisan karya ilmiah ini menggunakan metode Socio Legal. Metode Socio-legal adalah nama lain untuk istilah law and societies studies. Socio-legal studies adalah istilah generik untuk menyebutkan semua ilmu-ilmu sosial yang mempelajari hukum.

Dalam bahasa yang lain, socio-legal studies dianggap juga sebagai istilah generik untuk setiap pendekatan perspektif sosial terhadap hukum. Socio-legal studies berangkat dari asumsi bahwa hukum adalah sebuah gejala sosial yang terletak dalam ruang sosial dan dengan itu tidak bisa dilepaskan dari konteks sosial. Hukum bukanlah entitas yang sama sekali terpisah dan bukan merupakan bagian dari elemen sosial yang lain. Hukum tidak akan mungkin bekerja dengan mengandalkan kemampuannya sendiri sekalipun ia dilengkapi dengan perangkat asas, norma dan institusi. ${ }^{8}$

Hukum dapat dipelajari baik dari perspektif ilmu hukum atau ilmu sosial, maupun kombinasi diantara keduanya. Studi sosio-legal merupakan kajian terhadap hukum dengan menggunakan pendekatan ilmu hukum maupun ilmu-ilmu sosial. Studi hukum dinegara berkembang memerlukan kedua pendekatan baik pendekatan ilmu hukum maupun ilmu sosial. ${ }^{9}$ Menurut Sulistyowati Irianto Pendekatan dan analisis ilmu hukum diperlukan untuk mengetahui isi dari legislasi dan kasus hukum. Namun pendekatan ini tidak menolong memberi pemahaman tentang bagaimana hukum bekerja dalam kenyataan sehari-hari, dan bagaimana hubungan hukum dengan konteks kemasyarakatan. Atau bagaimana efektivitas hukum dan hubungannya dengan konteks ekologinya. Oleh karena itu dibutuhkan pendekatan interdisipliner, yaitu konsep dan teori dari berbagai disiplin ilmu dikombinasikan untuk mengkaji fenomena hukum, yang tidak diisolasi dari konteks-konteks sosial, politik, ekonomi, budaya, di mana hukum itu berada. ${ }^{10}$

\section{Pembahasan}

\section{Optik Sociolegal Putusan Mahkamah Konstitusi Nomor 85/PUU-XII/2013 Terhadap Uji Materiil Undang-Undang Nomor 7 Tahun 2004 Tentang Sumber Daya Air}

Perkembangan hukum sumber daya air mengalami pasang surut ditengah dinamika aspirasi masyarakat yang kian meluas sebagai akibat dari monopoli dan eksploitasi atas air. Guna menjamin sisi kepastian hukum, kemanfaatan dan keadilan dalam konteks penguasaan atas sumber daya air maka upaya uji materiil atau dikenal dengan istilah judicial review ditempuh guna menilai

\footnotetext{
8 Rikardo Simarmata, Socio-Legal Studies dan Gerakan Pembaharuan Hukum, Versi yang telah diedit dari tulisan ini telah dimuat dalam (Jakarta: Digest Law, Society \& Development, Volume I Desember 2007) hlm. 8.

9 Imam Koeswahyono dkk, Sosio Legal (Bekal Pengantar dan Substansi Pendalaman, (Malang: Intimedia, 2013) hlm. 15.

10 Adriaan W. Bedner, Sulistyowati Irianto dkk, Kajian Sosio-Legal (Seri Unsur-Unsur Penyusunan Bangunan Negara Hukum), (Jakarta: Universitas Indonesia, Universitas Leiden, Universitas Groningen, 2012) hlm. 2.
} 
konstitusionalitas norma yang terkandung di dalam Undang-Undang Sumber Daya Air. Sebelum dikeluarkannya Putusan Mahkamah Konstitusi Nomor 85/PUU-XII/2013 uji materill terhadap Undang-Undang Sumber Daya Air telah dilakukan dan Mahkamah Konstitusi memutus konstitusional bersyarat dengan memberikan pertimbangan-pertimbangan yang pada sebagian pokoknya sebagai berikut:

a. Karakteristik air yang merupakan bagian dari HAM, oleh karenanya negara memiliki peran dalam rangka melindungi, menghormati dan memenuhinya;

b. Negara dapat turut campur didalam melakukan pengaturan terhadap air. Sehingga Pasal 33 ayat (3) harus diletakkan di dalam konteks HAM dan merupakan bagian dari Pasal 28 H UUD 1945;

c. Bahwa air merupakan sebagai benda res commune, sehingga tidak dapat dihitung hanya berdasarkan pertimbangan nilai secara ekonomi. Konsep res commune, berimplikasi pada prinsip pemanfaat air harus membayar lebih murah;

d. Hak guna pakai air merupakan turunan dari hak hidup yang dijamin oleh UUD 1945 dan masuk ke dalam wilayah hukum publik yang berbeda dengan hukum privat yang bersifat kebendaan;

e. Peran swasta masih dapat dilakukan di dalam pengelolaan sumber daya air, selama peran negara masih ditunjukkan dengan merumuskan kebijakan, pengurusan, pengaturan, pengelolaan, dan pengawasan untuk tujuan sebesar-besarnya kemakmuran rakyat.

f. Berdasarkan pokok pertimbangan di atas, maka substansi Undang-Undang Nomor 7 Tahun 2004 tentang Pengelolaan Sumber
Daya Air tidak bertentangan dengan UUD 1945.

Beranjak dari putusan diatas maka salah satu hal yang masih menjadi perdebatan mengenai Pasal 33 UUD 1945 adalah tercantum didalam ayat (3) mengenai pengertian "hak penguasaan negara" atau ada yang menyebutnya dengan "hak menguasai negara". Sebenarnya ketentuan yang dirumuskan dalam Pasal 33 ayat (2) dan ayat (3) UUD 1945 tersebut sama persisnya dengan apa yang dirumuskan dalam Pasal 38 ayat (2) dan ayat (3) UUDS 1950, sehingga ada anggapan bahwa hal itu merupakan cerminan nasionalisme ekonomi Indonesia.

Dalam perspektif hukum adanya suatu jaminan bahwa negara memegang hak penguasaan atas air menjadi syarat yang tidak dapat ditiadakan dalam menilai konstitusionalitas Undang-Undang Sumber Daya Air. Dalam menilai konstitusionalitas norma penulis memandang bahwa rumusan Pasal 9 ayat (1) UU SDA membuka peluang privatisasi pengelolaan sumber daya air oleh swasta Sehingga, cenderung mengabaikan peran badan usaha negara meliputi BUMN dan BUMD dalam pengelolaan air, sebagaimana diamanatkan oleh ketentuan Pasal 33 ayat (2) UUD 1945. Studi kasus misalnya, di beberapa tempat di daerah pengambilan sumber daya air oleh perusahaan air minum melebihi ambang batas yang sudah ditentukan. Bahkan, disinyalir pengelolaan sumber daya air tanpa Analisis Mengenai Dampak Lingkungan (AMDAL). Akibatnya, terjadi kerusakan lingkungan yang merugikan masyarakat sekitar.

Beranjak dari pemahaman diatas maka manakala kita menganalisis terkait dengan penguasaan dan pengelolaan atas air maka tidak terlepas dari aspek hak yang sifatnya melekat. Dalam konsep pengelolaan atas air 
dikenal konsep hak dalam Hak Guna Air yang harus dibedakan dengan konsep hak dalam pengertian umum dan haruslah sejalan dengan konsep res commune yang tidak boleh menjadi objek harga secara ekonomi. Selain itu, Konsep Hak Guna Pakai Air dalam UU SDA harus ditafsirkan sebagai turunan (derivative) dari hak hidup (right to life) yang dijamin oleh UUD NRI Tahun 1945.

Oleh karenanya, pemanfaatan air di luar Hak Guna Pakai Air, dalam hal ini Hak Guna Usaha Air, haruslah melalui permohonan izin kepada Pemerintah yang penerbitannya harus berdasarkan pada pola yang disusun dengan melibatkan peran serta masyarakat yang seluasluasnya. Oleh karena itu, Hak Guna Usaha Air tidak boleh dimaksudkan sebagai pemberian hak penguasaan mutlak atas sumber air (baik dalam rumusan air tanah dan/atau air permukaan) sebagai contoh air sungai, danau, atau rawa.

Hak Guna Usaha Air merupakan instrumen dalam sistem perizinan yang digunakan Pemerintah untuk membatasi jumlah atau volume air yang dapat diperoleh atau diusahakan oleh yang berhak sehingga dalam konteks ini, izin harus dijadikan instrumen pengendalian, bukan instrumen penguasaan. Dengan demikian, swasta tidak boleh melakukan penguasaan atas sumber air atau sumber daya air tetapi hanya dapat melakukan pengusahaan dalam jumlah atau alokasi tertentu saja sesuai dengan alokasi yang ditentukan dalam izin yang diberikan oleh negara secara ketat.

Meskipun kondisi sosiologis yang diharapkan tidak sesuai dengan realitas empiris dilapangan terhadap pengelolaan air dalam kenyataanya praktek penswastaan pengelolaan air (bersih) dimulai sejak era Orde Baru. Setidaknya ada tiga perusahaan swasta asing yang mendapat konsesi mengelola air di sejumlah kota di
Indonesia. Pada tahun 1998, misalnya, PAM Jaya memberikan konsesi selama 25 tahun kepada Lyonnaise dan Thames untuk mengelola air bersih di Jakarta, mulai dari pengoperasian, pemeliharaan, hingga penetapan dan penarikan harga. Selain itu konsesi pengelolaan air juga diberikan PDAM Kota Batam kepada Biwater dan PDAM Kota Sidoarjo kepada United Water untuk hal yang sama.

Praktek empiris swastanisasi air bersih di Indonesia sebagaimana termaktub di dalam Undang-Undang Nomor 7 Tahun 2004 sebagian besar merupakan bentuk "campur tangan" Bank Dunia dalam menjalankan agenda reformasi di sektor air, yang bertujuan mendorong keterlibatan sektor swasta dalam pengelolaan dan komersialisasi sumber daya air. Menurut Bank Dunia, dalam makalah berjudul "Improving WaterResourcesManagement", ketersediaanair secara murah atau gratis sangat tidak ekonomis dan tidak efisien. Karena itu, masyarakat harus membayar atas air yang digunakan. Selain itu, terutama warga yang miskin butuh berbagai pilihan agar mendapatkan pelayanan sesuai dengan kemampuannya membayar. Bank Dunia menganggap sektor publik terlampau banyak memanfaatkan air bersih, bahkan 40-50 persen dari air yang dialokasikan untuk sektor itu hilang karena kebocoran dan pencurian. Hal ini dinilai membebani keuangan negara, sekaligus mengurangi kemampuan pemerintah dalam memperluas pelayanan air bersih ke wilayah kumuh dan pinggir perkotaan. Karena itu, pilihan untuk mengelola sumber daya air secara efektif adalah menjadikan air sebagai komoditas ekonomi dan harus dikelola swasta agar dapat mengembalikan biaya operasi, memperbaiki pelayanan, dan meningkatkan akses air bersih kepada masyarakat lebih luas. 
Namun demikian praktek penswastaan pengelolaan air bersih di sejumlah negara justru mengalami kemunduran. Laporan The Transnational Institute tahun 2010, misalnya, memperlihatkan, 180 kota di 35 negara telah mengembalikan sistem pengelolaan air bersih di bawah kontrol negara. Bahkan, International Finance Corporation (IFC) yang banyak membiayai program penswastaan air bersih mengakui, dari 85 program yang disusun pada tahun 2007, hanya 22 diantaranya yang berjalan pada 2013. Bahkan, 63 program yang dibiayai IFC sendiri telah gagal dan sulit berkembang secara ekonomis.

Pasca putusan MK meski logikanya benar, penswastaan sumber daya air dalam praktik tampak tidak berjalan efektif dan cenderung gagal. Hal itu disebabkan penentuan dan penerapan serta kenaikan tarif air bersih selalu tidak diimbangi kualitas dan pelayanan yang lebih baik. Belum lagi hasil keuntungan digunakan bukan untuk memperluas akses air bersih bagi warga miskin dan warga yang tinggal di daerah kumuh dan pinggir kota. Pasca putusan Mahkamah Konstitusi, pemerintah dituntut untuk merumuskan kebijakan sumber daya air yang tepat, terutama dalam memenuhi hak masyarakat atas air. Dewasa ini diperkirakan 32,2 persen penduduk Indonesia belum punya akses air bersih. Umumnya mereka mendapatkan air dari sungai yang terpolusi, air tanah yang terkontaminasi, atau air yang dibeli dengan harga mahal dari pedagang air. Air tak ubahnya minyak yang sulit diperoleh dan mahal.

Senyampang menelaah konstruksi hukum pada putusan Mahkamah Konstitusi sebagaimana telah dipaparkan diatas maka penulis memandang bahwa kebijakan di bidang pengelolaan Sumber Daya Air pasca penetapan Putusan MK tentu memiliki dampak sistemik terhadap rezim regulasi di bidang sumber daya air. Ketentuan Undang-Undang Sumber Daya Air yang dibatalkan Mahkamah Konstitusi memiliki turunan aturan berbentuk Peraturan Pemerintah (PP) yaitu ; 1. PP 16 Tahun 2005 tentang Pengembangan Sistem Penyediaan Air Minum, 2. PP 20 Tahun 2006 tentang Irigasi, 3. PP 42 Tahun 2008 tentang Pengelolaan Sumber Daya Air, 4. PP 43 Tahun 2008 tentang Air Tanah, 5. PP 38 Tahun 2011 tentang Sungai, 6. PP 73 Tahun 2013 tentang Rawa, dan 7. PP 69 Tahun 2014 tentang Hak Guna Air, dimana 6 (enam) dari 7 (tujuh) peraturan pemerintah tersebut (selain PP 69 Tahun 2014 tentang Hak Guna Air) harus dipertimbangkan bahwasanya keenam PP tersebut juga tidak memenuhi enam prinsip pembatasan pengeloaan sumber daya air

Artinya bisa dikatakan bahwa keenam PP tersebut juga bertentangan dengan konstitusi. Peraturan pemerintah memang bukan menjadi kewenangan Mahkamah Konsitusi untuk menguji, tetapi mengingat ketentuan UndangUndang a quo yang di uji adalah "roh" atau "jantung" dari hak penguasaan oleh negara atas sumber daya air yang menggantungkan hajat hidup orang banyak sehingga peraturan pelaksana Undang-Undang a quo juga harus diperiksa secara seksama dan semata-mata karena persyaratan konstitusionalitas undangundang yang diuji dan mengimplementasikan penafsiran Majelis Hakim Mahkamah Konstitusi.

\section{Arah Politik Hukum Pengelolaan Sumber Daya Air Pasca Putusan Mahkamah Konstitusi Nomor 85/ PUU-XII/2013}

Pasca penetapan Putusan Mahkamah Konstitusi Nomor 85/PUU-XII/2013 maka politik hukum dan kebijakan di bidang sumber daya air haruslah mengalami pergeseran 
paradigma penguasaan hak atas air yang bertumpu pada sebesar-besarnya kemakmuran rakyat sebagaimana amanat konstitusi. Penulis memandang bahwasanya politik perundangundangan di bidang Sumber Daya Air merupakan bagian dari sistem hukum nasional yang sangat berperan dalam pembangunan hukum nasional untuk mewujudkan sistem hukum nasional berdasarkan Pancasila dan Undang-Undang Dasar Negara Republik Indonesia Tahun 1945.

Kajian teoritik-akademik ilmu perundangundangan tidak akan pernah terlepas dari aspek politik yang berjalan secara beriringan dengan aspek hukum dalam bingkai politik hukum ketatanegaraan. Menurut Mahfud MD, ${ }^{11}$ politik hukum adalah legal policy atau garis (kebijakan) resmi tentang hukum yang akan diberlakukan baik dengan pembuatan hukum baru maupun dengan penggantian hukum lama, dalam rangka mencapai tujuan negara.

Dengan demikian politik hukum merupakan pilihan tentang hukum-hukum yang akan diberlakukan sekaligus pilihan tentang hukumhukum yang akan dicabut atau tidak diberlakukan yang kesemuanya dimaksudkan untuk mencapai tujuan negara seperti yang tercantum dalam Pembukaan Undang-Undang Dasar Negara Republik Indonesia Tahun 1945. L.J.Van Apeldorn berpendapat politik hukum sebagai politik perundang-undangan yang artinya politik hukum tersebut ialah menetapkan tujuan dan isi peraturan peraturan perundang-undangan. Dari pendapat kedua ahli hukum tersebut dapat kita sarikan bahwa politik hukum merupakan sebuah kebijakan tentang hukum yang akan di terapkan maupun penggantian hukum yang sudah di terapkan dengan menetapkan tujuan dan isi dari pembentukan sebuah peraturan perundang-undangan.

Penjabaran diatas dipertegas oleh pendapat yang diutarakan oleh Satjipto Rahardjo, menurut pendapat Satjipto Rahardjo ${ }^{12}$ mendefinisikan politik hukum sebagai aktifitas memilih dan cara yang hendak dipakai untuk mencapai suatu tujuan sosial dengan hukum tertentu di dalam masyarakat yang cakupannya meliputi jawaban atas beberapa pertanyaan mendasar yaitu, 1) tujuan apa yang hendak dicapai melalui sistem yang ada, 2) cara-cara apa dan yang mana dirasa paling baik untuk dipakai dalam mencapai tujuan terebut, 3) kapan waktunya dan melalui cara bagaimana hukum itu perlu diubah, 4) dapatkah suatu pola yang baku dan mapan dirumuskan untuk membantu dalam memutuskan proses pemilihan tujuan serta cara-cara untuk mencapai tujuan tersebut dengan baik.

Sebagaimana termatub di dalam rezim Undang-Undang Nomor 12 Tahun 2011 tentang Pembentukan Peraturan Perundang-Undangan maka implikasi hukum pasca penetapan Putusan Mahkamah Konstitusi yang membatalkan suatu norma peraturan perundang-undangan maka terhadap eksistensi norma sebagaimana dimaksud dinyatakan tidak memiliki kekuatan hukum yang mengikat lagi oleh karenanya harus dilakukan pengaturan kembali dan/ atau penyempurnaan materi dalam rangka menciptakan kepastian hukum, kemanfaatan dan keadilan dengan memperrtimbangkan Putusan hakim sebagaimana dimaksud.

11 Moh, Mahfud MD, Politik Hukum di Indonesia, (Jakarta, PT.Raja Grafindo Persada, 2009) hlm. 1.

12 Satjipto Rahardjo, Sosiologi Hukum: Perkembangan, Metode dan Pilihan Masalah, (Surakarta: UMS Press, 2002) hlm. 38. 
Guna menghindari adanya kekososongan hukum dalam konteks pengelolaan sumber daya air maka penulis memandang bahwa dengan mengacu pada amar putusan Mahkamah Konstitusi pada poin 5 memutuskan Undang-Undang Nomor 11 Tahun 1974 tentang Pengairan untuk diberlakukan kembali agar tidak terjadi kekosongan hukum, khususnya menyangkut sumber daya air di Indonesia. Mengisi kekosongan hukum tidak berarti otomatis menjadi pengganti dasar hukum atas seluruh peraturan pemerintah dan produk tata usaha negara lainnya yang telah dikeluarkan oleh pemerintah yang undang-undangnya telah dibatalkan. Ada dua kemungkinan yang bisa dilakukan:

Pertama menghidupkan kembali seluruh peraturan pemerintah yang menjadi turunan dari Undang-Undang Nomor 11 Tahun 1974 tentang Pengairan, sebagaimana perintah undang-undang tersebut. Setidaknya terdapat 7 Peraturan Pemerintah yang dirujuk oleh undang-undang tersebut, yaitu 1. PP tentang Penguasaan oleh Negara, 2. PP tentang Pengaturan Wewenang, 3. PP tentang Tata Cara Pembinaan, 4. PP tentang Pengusahaan, 5. PP tentang Bangunan Pengairan, 6. PP tentang Perlindungan, dan 7. PP tentang Pembiayaan.

Kedua melihat kesesuaian hukum dan pertentangannya antara aturan pelaksanaan dari Undang-Undang Nomor 7 Tahun 2004 tentang Sumber Daya Air berupa Peraturan Pemerintah dengan Undang-Undang yang kembali diberlakukan oleh MK yaitu UndangUndang Nomor 11 Tahun 1974. Aturan turunan dari Undang-Undang a quo adalah 1. PP 16 Tahun 2005 tentang Pengembangan Sistem Penyediaan air Minum, 2. PP 20 Tahun 2006 tentang Irigasi, 3. PP 42 Tahun 2008 tentang Pengelolaan Sumber Daya Air, 4. PP 43 Tahun
2008 tentang Air Tanah, 5. PP 38 Tahun 2011 tentang Sungai, 6. PP 73 Tahun 2013 tentang Rawa, dan 7. PP 69 Tahun 2014 tentang Hak Guna Air.

Harmonisasi dan sinkronisasi hukum dipandang penting manakala terdapat perbedaan mendasar kontekstualisasi paradigma penguasaan atas sumber daya air antara aturan Undang-Undang Nomor 11 Tahun 1974 tentang Pengairan dengan aturan turunan Undang-Undang Nomor 7 Tahun 2004 tentang Sumber Daya Air. Maruah substansi dari Undang-Undang Nomor 11 Tahun 1974 tentang Pengairan mengedepankan pengelolaan sumber daya air dengan pendekatan tanggungjawab negara (penguasaan negara) yang mengutamakan kepentingan kebutuhan sosial (hajat hidup orang banyak) dan pelibatan masyarakat dalam perencanaan pengusahaan, perlindungan dan pembiayaan atas manfaat dari pengairan serta belum detail mengatur soal pemanfaatan air untuk kepentingan industri ekstrakitf lainnya.

Sedangkan maruah substantif dari ketentuan Undang-Undang Nomor 7 Tahun 2004 tentang Sumber Daya Air dalam pengelolaannya menggunakan pendekatan tanggung-jawab negara yang mengutamakan pengelolaan ekosistem dan sebesar-besarnya membuka peluang untuk melibatkan pihak swasta (private sektor), baik untuk kepentingan kebutuhan sosial maupun kebutuhan penguasaan sumber air untuk kepentingan industri ekstraktif dan komersil lainnya.

Selain daripada itu bisa diidentifikasi bahwa seluruh perusahaan-perusahaan swasta yang memanfaatkan sumber daya air pasca putusan tersebut tidak lagi memiliki kekuatan hukum untuk memanfaatkan sumber daya air, baik sebagai bahan kebutuhan produksi 
utama perusahaan (perusahaan air kemasan) maupun sebagai kebutuhan pendukung produksi perusahaan (perusahaan tambang, perkebunan, dan lain-lain). Di banyak tempat, konflik sosial yang ditimbulkan atas penguasaan air secara sepihak ini menimbulkan konflik dengan masyarakat sekitar (studi kasus konflik dikawasan pegunungan kendeng, konflik sumber air di Kota Batu, dan lain-lain). Selain karena semakin kecilnya akses bahkan ada yang kehilangan akses masyarakat atas sumber air, masyarakat juga sebagai korban dampak buruk yang ditimbulkan oleh penguasaan serta kerusakan lingkungan hidup dan sumber daya alam karena aktivitas eksploitatif dan ekstraktif yang kian massif dan meluas.

Aktivitas perusahaan yang masih terus menerus memanfaatkan sumber daya air tanpa kekuatan hukum yang jelas atau secara illegal, bisa dikategorikan sebagai bentuk pencurian atau perampasan sumber daya alam yang dapat menimbulkan kerugian negara sebagaimana tercantum pada Pasal 15 Ayat (1) huruf b, dan itu adalah kejahatan sebagaimana tercantum pada Pasal 15 Ayat (2) Undang-Undang Nomor 11 Tahun 1974 tentang Pengairan.

Berdasarkan pertimbangan diatas maka penulis mensitir gagasan Suteki tentang rekonstruksi politik hukum hak menguasai negara atas sumber daya air yang didesain melalui pendekatan prismatik guna menjamin terwujudnya gagasan cita hukum baik dari aspek kepastian hukum, kemanfaatan dan keadilan. Adapun desain politik hukum sebagaimana dimaksud dapat diilustrasikan melalui skema sebagai berikut:

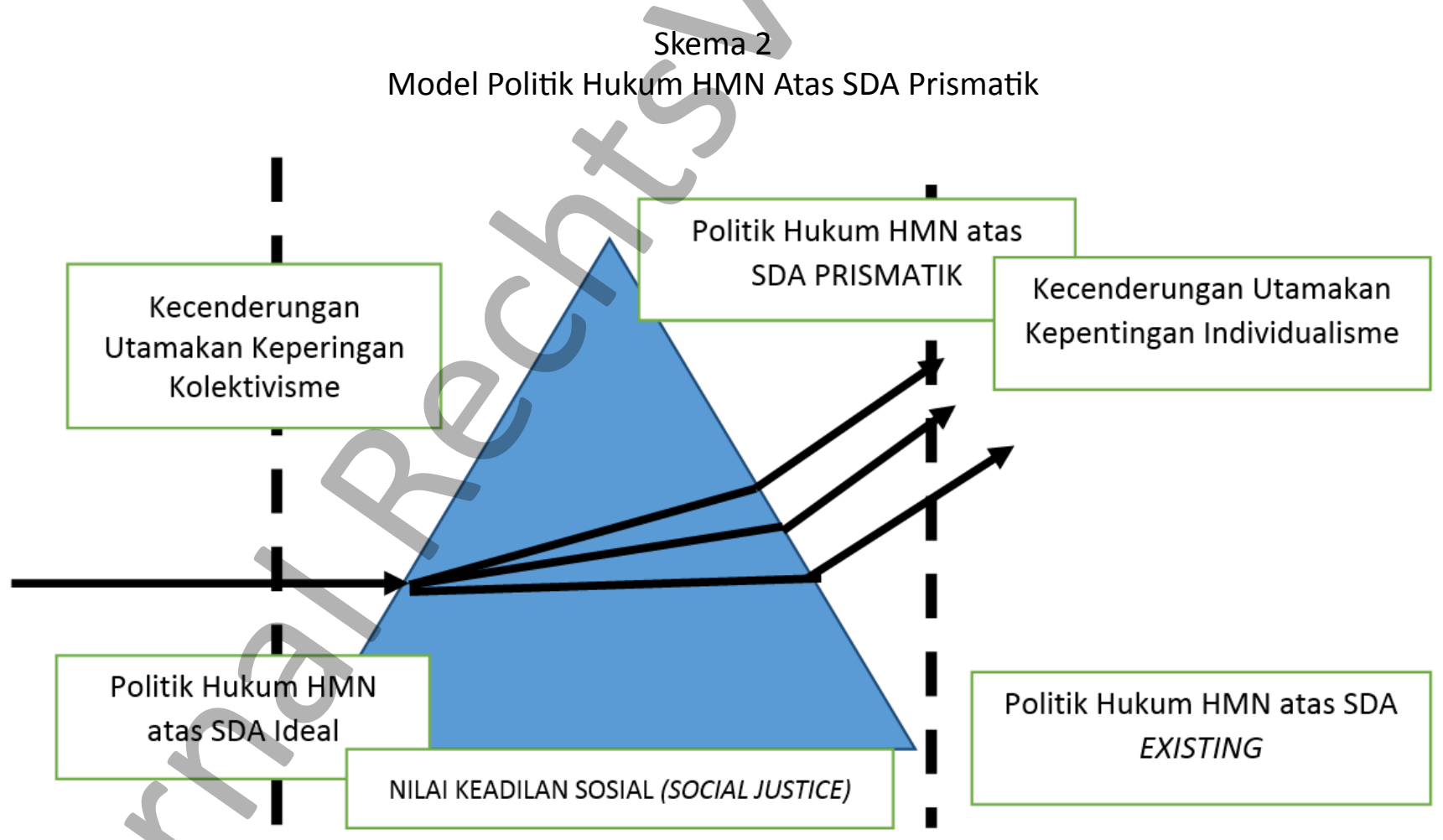

Sumber: Hasil Adaptasi dari Fredd W. Riggs (Suteki Dalam Bukum Rekonstruksi Politik Hukum Hak Atas Air Pro Rakyat hlm 289) 
Berdasarkan skema diatas maka mengutip pendapat dari I Nyoman Nurjaya ${ }^{13}$, mengatakan bahwa penyelenggaraan pembangunan nasional yang hanya diabdikan demi peningkatan pendapatan dan devisa negara (state revenue), maka pemanfaatan SDA dilakukan tanpa memperhatikan prinsip-prinsip keadilan, demokratisasi, dan keberlanjutan fungsi sumber daya alam. Hal ini merupakan salah satu wujud timbulnya permasalahan lingkungan hidup. Atas dasar pertimbangan dimaksud maka proses dialektis untuk menemukan konstruksi baru politik hukum tentang hak menguasai negara atas sumber daya air berbasis nilai keadilan sosial dapat dijelaskan melalui ragaan tersebut ditunjang dengan ragaan dialektis antara politik hukum tentang hak menguasi negara atas Sumber Daya Air yang ideal dan existing sebagai berikut:

Tabel 1. Dialog Politik Hukum tentang HMN atas SDA Ideal dan Existing

\section{Politik Hukum HMN SDA Ideal}

\section{Politik Hukum HMN SDA Existing}

Dasar: Pelimpahan tugas kewenangan bangsa, Pasal 33 ayat (1), (2), dan (3) $\rightarrow$ Memiliki karakteristik Sosialisme

Subyek: Negara RI (Pemerintah dan Rakyat) bukan hubungan subordinasi.

Tujuan: Sebesar-besar kemakmuran rakyat, keadilan sosial. Dalam rangka mewujudkan politik hukum HMN atas SDA maka fungsi sosial air dan keadilan sosial di bidang SDA diutamakan. Salah satu upaya yang dapat ditempuh adalah elalui evaluasi terhadap produk hukum dibidang pengelolaan Sumber Daya Air yang bertentangan dengan konstitusi dan nilai keadilan sosial.
Dasar: Pelimpahan tugas kewenangan bangsa, Pasal 33 ayat (3) dan ayat (5) $\rightarrow$ Memiliki karakteristik Neo Liberalisme.

Subyek: Negara RI (diwakili oleh pemerintah atau pemerintah daerah) mengarah pada swasta yang dapat diambil alih. Hubungan rakyat dan pemerintah bersifat subordinatif.

Tujuan Bergeser dari sebesar-besar kemakmuran rakyat kepada keadilan distributif (individual) 
Substansi:

a. Kepentingan kolektif diutamakan bukan kepentingan orang-perorang;

b. Negara menguasai bumi, air, dan kekayaan alam yang terkandung didalamnya. Air sebagai benda sosial (res commune);

c. Produksi dari semua, oleh semua dan untuk semua yang didasarkan atas asas usaha bersama dan kekeluargaan;

d. Negara mengakui hak individu untuk ikut serta dalam pengelolaan sumber daya alam secara terbatas;

e. Negara harus menguasai cabang-cabang produksi yang penting bagi negara dan menguasai hajat hidup orang banyak, kalau tidak tampuk produksi akan jatuh ke tangan orang-seorang yang berkuasa dan rakyat banyak ditindasinya;

f. Hanya perusahaan yang tidak menguasai hajat hidup orang banyak boleh ada di tangan orangperorangan. (Dalam konteks Politik Hukum HMN atas SDA Prismatik berbasis nilai keadilan sosial maka pihak swasta hanya diberikan kesempatan untuk andil maksimal $49 \%$ saham perusahaan)

g. Negara berwenang untuk merumuskan kebijakan (beleid), melakukan tindakan pengurusan (bestuursdaad), melakukan pengaturan (regelendaad), melakukan pengelolaan (beheersdaad), dan melakukan pengawasan (toezjchthoudendaad);

h. Negara harus menghormati (to respect), melindungi (to protect), dan memenuhi (to fulfil), hak atas air rakyat mengingat hak atas air merupakan bagian dari rezim Hak Asasi Manusia.

Konsekuensi negara sebagai regulator dan pengelola cabang-cabang produksi yang penting bagi negara dan yang menguasai hajat hidup orang banyak.

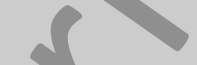

Substansi:

a. Kepentingan kolektif semakin direduksi oleh kepentingan swasta bahkan asing;

b. Negara berusaha untuk melepaskan tanggung jawab pengelolaan sumber daya alam untuk sebesar-besar kemakmuran rakyat kepundak swasta bahkan asing. Air sebagai komiditi, benda ekonomi (commercial good);

c. Produksi cenderung diarahkan pada pemenuhan kebutuhan air bagi yang mampu;

d. Negara mengakui hak guna (HGU dan HG Pakai) dan Hak Ulayat atas SDA;

e. Negara tidak harus menguasai cabangcabang produksi yang penting bagi negara dan menguasai hajat hidup orang banyak;

f. Kewenangan negara menguasai SDA semakin direduksi hanya sebagai regulator yaitu untuk:

1) Mengatur dan menyelenggarakan peruntukan, penggunaan, persediaan, dan pemeliharaan SDA dalam bentuk hak guna; dan

2) Menentukan dan mengatur hubunganhubungan dan perbuatan-perbuatan hukum antara orang-orang dengan SDA dalam betuk hak guna;

g. Tidak menafikkan perorangan atau swasta berperan dalam produksi/pengelolaan sumber daya alam. Termasuk yang menguasai hajat hidup orang banyak. Pengusahaan migas, listrik dan air minum dapat dikuasai oleh swasta nasional $100 \%$ dan swasta asing 95\%.

Konsekuensi, kecenderungan negara melulu sebagai regulator. Pengusahaan air mulai diserahkan pada mekanisme pasar. Privatisasi tanpa batas. (Penguasaan modal swasta dapat mencapai $100 \%$ dan modal asing dapat mencapai 95\%)

Sumber: Hasil Adaptasi dari Fredd W. Riggs (Suteki Dalam Buku Rekonstruksi Politik Hukum Hak Atas Air Pro Rakyat hlm 290) 
Berdasarkan pada desain prismatik diatas maka arah politik hukum terhadap pengelolaan sumber daya air pasca penetapan Putusan Mahkamah Konstitusi Nomor 85/PUU-XII/2013 Sebagai Keniscayaan Terwujudnya Kedaulatan Sumber Daya Air Di Indonesia diarahkan pada konstruksi hukum hak mengusasi negara (HMN) atas Sumber Daya Air berbasis pada nilai-nilai keadilan sosial sebagaimana diamanatkan oleh sila ke V dari dasar negara Pancasila. Rekonstruksi politik hukum dilakukan pada tataran dasar, subjek, tujuan substansi serta konsekuensinya sehingga terwujud desain pengelolaan sumber daya air yang berbasis pada Neo Sosialisme Indonesia dengan menekankan partisipasi rakyat yang luas dalam bidang pengelolaan sumber daya air di masa yang akan datang.

\section{Penutup}

Berdasarkan pembahasan sebagaimana telah diuraikan diatas maka dalam penulisan karya ilmiah ini dapat disimpulkan bahwa dalam optik kajian sociolegal terhadap Putusan Mahkamah Konstitusi Nomor 85/PUU-XII/2013 mengenai uji materiil Undang-Undang Nomor 7 Tahun 2004 tentang Sumber Daya Air menunjukkan bahwa pergeseran paradigma penguasaan sumber daya air oleh swasta dan/atau pihak asing yang bersifat monopoli dan eksploitatif memiliki potensi untuk menimbulkan konflik sosial (sebagai contoh Konflik Sosial dikawasan CAT Watu Putih, Konflik SDA di wilayah Bulukerto Bumi Aji, Penguasaan Saham PAM Jaya dII). Melalui Putusan tersebut diharapkan maruah Hak Menguasai Negara Atas Sumber Daya Air menjadi bagian yang tidak terpisahkan dari tanggung jawab negara (state responsibility) sebagaimana amanat Pancasila dan UUD NRI Tahun 1945.
Arah politik hukum pengelolaan Sumber Daya Air pasca Putusan Mahkamah Konstitusi Nomor 85/PUU-XII/2013 sebagai keniscayaan terwujudnya kedaulatan Sumber Daya Air di Indonesia dikonstruksikan melaui desain konstitusional politik hukum Hak Menguasai Negara (HMN) Atas Sumber Daya Air Prismatik yang melahirkan gagasan Neo Sosialisme Indonesia dengan menekankan nilai-nilai keadilan sosial dan partisipasi rakyat yang luas dalam bidang pengelolaan sumber daya air.

Berdasarkan kesimpulan diatas maka dalam penulisan karya ilmiah ini di rekomendasikan beberapa sumbangsih saran antara lain:pertama, seyogyanya Pemerintah dan DPR segera melakukan revisi terhadap ketentuan Undang-Undang Nomor 7 Tahun 2004 tentang Sumber Daya Air guna mewujudkan kedaulatan atas Sumber Daya Air. Agar menjamin tidak terjadi kekosongan hukum (rechts vacuum) maka perlu dipertimbangkan putusan Mahkamah Konstitusi untuk mengembalikan desain pengelolaan sumber daya air melalui Undang-Undang Nomor 11 Tahun 1974 tentang Pengairan. Dalam rangka evaluasi secara menyeluruh maka politik hukum perundangundangan di bidang sumber daya air diarahkan pada upaya untuk mengkonstruksikan gagasan Hak Menguasi Negara atas (HMN) atas Sumber Daya Air yang berlandaskan pada semangat neososialisme sebagaimana amanat dari Pancasila dan UUD NRI Tahun 1945.

Kedua, Seyogyanya Pemerintah melakukan harmonisasi dan sinkronisasi hukum terhadap aturan pelaksanaan dari Undang-Undang Nomor 7 Tahun 2004 tentang Sumber Daya Air meliputi (1) PP 16 Tahun 2005 tentang Pengembangan Sistem Penyediaan air Minum, (2) PP 20 Tahun 2006 tentang Irigasi, (3) PP 42 Tahun 2008 tentang Pengelolaan Sumber Daya 
Air, (4) PP 43 Tahun 2008 tentang Air Tanah, (5) PP 38 Tahun 2011 tentang Sungai, (6) PP 73 Tahun 2013 tentang Rawa, dan (7) PP 69 Tahun 2014 tentang Hak Guna Air. Sehingga tercipta konsistensi hukum yang berpedoman pada amanat Pancasila, Konstitusi dan Putusan Mahkamah Konstitusi Nomor 85/PUU-XII/2013.

Ketiga,Seyogyanya Pemerintah melakukan identifikasi guna mengeluarkan kebijakan agar sumber daya air dimasukkan dalam kategori bidang usaha yang tertutup dari penanaman modal, dengan pertimbangan bahwa di dalam Putusan Mahkamah Konstitusi Nomor 85/PUUXII/2013 telah memberikan tafsir konstitusi bahwa "hak menguasai negara" atau disebut dengan istilah HMN meletakkan peringkat pertama pada pengelolaan sendiri oleh negara atas sumber daya alam ke arah sebesar-besar kemakmuran rakyat, sehingga negara wajib mengelola sumber daya air secara mandiri untuk pemenuhan kebutuhan sehari-hari dan kebutuhan pertanian seluruh rakyat Indonesia dengan memperhatikan hak atas sumber daya air sebagai bagian yang tidak terpisahkan dari hak hidup (right to life) yang melekat pada setiap manusia (in persona) dan tidak diperlukan pihak ketiga dalam pengelolaan sumber daya air yang dapat membukan peluang terjadinya konflik pengelolaan sumber daya air.

\section{Daftar Pustaka}

\section{Buku}

Bedner,Adriaan W, Sulistyowati Irianto dkk, Kajian Sosio-Legal (Seri Unsur-Unsur Penyusunan Bangunan Negara Hukum), (Jakarta:Universitas Indonesia, Universitas Leiden, Universitas Groningen, 2012)

Endaryanta, Edwin, Politik Air di Indonesia: Penjarahan si Gedhang oleh Korporasi Aqua Danone, (Yogyakarta: Laboratorium IImu Pemerintahan, FISIPOL UGM, 2007)
Koeswahyono, Imam dkk, Sosio Legal (Bekal Pengantar dan Substansi Pendalaman, (Malang: Intimedia, 2013)

Mahkamah Konstitusi, Akhir Kisah Privatisasi Air (UU SDA Bertentangan dengan Konstitusi), (Jakarta: Majalah Konstitusi, 2015)

Moh, Mahfud MD, Politik Hukum di Indonesia, (Jakarta, PT.Raja Grafindo Persada, 2009)

Nurjaya, I Nyoman, Pengelolaan Sumber Daya Alam dalam Perspektif Antropologi Hukum, (Malang: diterbitkan atas kerjasama Program Magister Ilmu Hukum Program Pascasarjana, Arena Hukum Majalah Fakultas Hukum Universitas Brawijaya dengan Penerbit Universitas Negeri Malang (UM Press), 2006)

Rahardjo,Satjipto, Sosiologi Hukum: Perkembangan, Metode dan Pilihan Masalah, (Surakarta: UMS Press, 2002)

Simarmata,Rikardo, Socio-Legal Studies dan Gerakan Pembaharuan Hukum, Versi yang telah diedit dari tulisan ini telah dimuat dalam (Jakarta: Digest Law, Society \& Development, Volume I Desember 2007)

Sugiri, Bambang, Pergeseran Kebijakan Hukum Pidana Tentang Pencemaran Lingkungan Hidup Dalam Undang-Undang Nomor 32 Tahun 2009 Tentang Perlindungan Dan Pengelolaan Lingkungan Hidup, (Malang: Disertasi PDIH FH UB, 2012)

Suteki, Rekonstruksi Politik Hukum Hak Atas Air ProRakyat, (Malang: Surya Pena Gemilang, 2010)

Wignyosoebroto,Soetandyo, Hukum Paradigma, Metode dan Masalah, (Jakarta: Elsam dan Huma, 2002)

\section{Peraturan}

Undang-Undang Dasar Negara Republik Indonesia Tahun 1945

Undang-Undang Nomor 7 Tahun 2004 tentang Sumber Daya Air

Undang-Undang Nomor 11 Tahun 1974 tentang Pengairan

Putusan Mahkamah Konstitusi Nomor 85/PUUXII/2013

Putusan Mahkamah Konstitusi Nomor 008/PUUIII/2005

Putusan Mahkamah Konstitusi Nomor 058-059-060063/PUU-II/2004 